\title{
The color of illumination affects the stress response of jundiá (Rhamdia quelen, Quoy \& Gaimard, Heptapteridae)
}

\author{
A cor da iluminação afeta a resposta ao estresse em jundiá (Rhamdia quelen, Quoy \& Gaimard, 1824, \\ Heptapteridae)
}

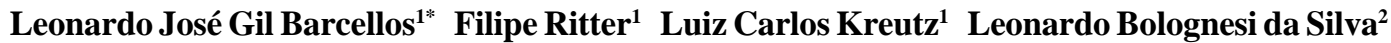 \\ Leonardo Cericato ${ }^{3}$ Rosmari Mezzalira Quevedo ${ }^{4}$
}

\begin{abstract}
This paper provides the first data about physiological responses to stress in jundiá (Rhamdia quelen) exposed to different light colours. Jundiá is a species for fish production in the southern part of South America - and suitable for any region with a temperate or subtropical climates. In order to develop a light management for jundiá fingerlings during indoor maintenance and to understand the relationship between welfare and light colour in the jundiá, fingerlings were exposed to white, blue and green light. At the $10^{\text {th }}$ day of light exposure an acute stressor was imposed. One hour after the application of the stressor, fish were sampled. Stress was assessed by means of cortisol determination. Our results show that green light seems to be the worst alternative to illuminate jundiá indoor experimentation facilities, or even fish transportation. The results also suggests that colour affects the stress response of jundia, and may be usefull for the management of this species.
\end{abstract}

Key words: stressors, light spectrum, cortisol, Rhamdia, silver catfish.

\section{RESUMO}

Este artigo traz os primeiros resultados sobre a resposta ao estresse em jundiá (Rhamdia quelen) expostos a diferentes cores de luz. O jundiá é uma espécie para produção no sul da América do Sul - sendo assim apta a cultivo em qualquer região de clima temperado e subtropical. Com o objetivo de desenvolver um manejo de luz para o jundiá durante sua manutenção em tanques internos e de entender a relação entre as cores de luz e o bem-estar da espécie, alevinos foram exposto por 10 dias à luz branca, azul e verde. No $10^{\circ}$ dia de exposição às diferentes cores de luz, um estressor agudo foi imposto. Uma hora após a aplicação do estressor, os peixes foram amostrados e a resposta ao estresse medida por meio da determinação da concentração sérica de cortisol. Nossos resultados mostraram que a luz verde parece ser a pior alternativa para iluminar instalações internas ou de transporte de jundiás. Os resultados também sugerem que a cor da luz afeta a resposta ao estresse dos jundiás, conhecimento que pode ser útil no manejo da espécie.

Palavras-chave: espectro de luz, cortisol, Rhamdia, Silver Catfish.

\section{INTRODUCTION}

The stress response is the reaction of an organism to a diversity of adverse factors named stressors and comprises a number of physiological processes largely coordinated by the hypothalamus pituitary - interrenal cells (HPI) axis. Cortisol, the end product of the HPI axis, plays several physiological actions (reviewed by BARTON \& IWAMA, 1991 and WENDELAAR BONGA, 1997) and is generally measured in fish blood to assess the stress response. Jundiá (Rhamdia quelen, Quoy \& Gaimard, 1824) is a suitable species for fish production in the southern part of South America - and probably for any region with temperate or subtropical climate

\footnotetext{
${ }^{1}$ Universidade de Passo Fundo (UPF), Curso de Medicina Veterinária. Campus Universitário do Bairro São José, BR 285, Km 171, CP 611, 99001-970, Passo Fundo, RS, Brasil. * Autor para correspondência. E-mail: lbarcellos@upf.br.

${ }^{2}$ Universidade Federal do Rio Grande do Sul (UFRGS). Av. Bento Gonçalves 7712, 91540-000, Porto Alegre, RS, Brasil.

${ }^{3}$ Centro de Aqüicultura da Universidade Estadual Paulista (UNESP). Via de Acesso Prof. Dr. Paulo Donato Castellane, s/n, 14884900, Jaboticabal,SP, Brasil.

${ }^{4}$ Laboratório de Piscicultura, UPF. Campus Universitário São José, CP 611, 99001-970, Passo Fundo, RS, Brasil.
} 
(BARCELLOS et al., 2001). Today, the sequence for jundiá culture is hatchery, larviculture (1-6g), nursery (from 5-6g to 30-60g) and growout (from 30-60g to 600$800 \mathrm{~g})$. Larviculture is divided into three distinct phases. During the first phase after hatching the larvae are kept in incubators until the yolk is completely absorbed; during the second phase, the larvae grow until commercial weigth for fingerling sales, and in the third phase, they are kept indoor laboratory conditions until expedition to the fish farms. This phase is highly stressing for jundiá due to the maintainance at high densities, handling (capture of each batch of fingerlings for sale), a noisy and disturbing environment, and dietary changes (from plankton to artificial food). These practices may provoke a characteristic stress response. Research on practices that may reduce the stress level in this phase are necessary in order to prevent severe losses due to stress and, consequently, parasitic and bacterial infections.

Very few studies have evaluated the effects of background and light spectrum on fish. The colour of the light has been reported to be a modulating factor for the stress response on Nile tilapia Oreochromis niloticus L. (VOLPATO \& BARRETO, 2001) and also to affect Nile tilapia reproduction (VOLPATO et al., 2004). ROTLANT et al. (2003) reported that a white background affected the stress response in Pagrus pagrus (Linnaeus).

The present study aims to verify the possible effect of colour light regime on the stress response of jundiá. Blue and green lights were tested because they reach deeper waters and are therefore widespread in fish environments (VOLPATO \& BARRETO, 2001).

\section{MATERIAL AND METHODS}

The study was conducted at the facilities of the University of Passo Fundo (RS, Brazil, 28¹5'S / $52^{\circ} 24$ ”'W, $687 \mathrm{~m}$ above sea level). Two hundred and forty 90-day old ( $8 \pm 0.8 \mathrm{~g})$, mixed sex jundiá fingerlings were tranferred to 2440 -l plastic aquaria, distributed in three isolated compartiments with black plastic covers in the same experimental room, and filled with aerated fresh water (final fish density of $2 \mathrm{~g} / \mathrm{l}$ ). Water was exchanged at a rate of $20 \%$ per day, at the same moment that food wastes were removed. During an acclimation period of five days, the fish were kept under natural photoperiod and fed twice a day (10.00 and $16.00 \mathrm{~h}$ ) with commercial food ( $42 \%$ crude protein, $3,400 \mathrm{kcal} / \mathrm{kg} \mathrm{DE}$ ), at $5 \%$ of body weight.

Throughout the experiment water temperature averaged $22 \pm 1^{\circ} \mathrm{C}$, $\mathrm{pH}$ ranged from 6.2 to 7.0 and dissolved oxygen ranged from 5.6 to $7.5 \mathrm{mg} / \mathrm{L}$.
Total ammonia was lower than $0,5 \mathrm{mg} / \mathrm{L}$. The total hardness and alkalinity were respectively 60 and 65mg/ $\mathrm{L} \mathrm{CaCO}_{3}$. Lights were turned on from 6:00 to 18:00h.

After the acclimation period, the three aquaria compartiments were isolated, with fluorescent as the only light source. During ten days, the fish were maintained under 12 hour light: 12 hour dark, with white, blue and green light imposed in each compartment by different colour lamps (AZOO ${ }^{\mathrm{TM}}$ Super Light White AZ20013, 30W, 580nm; AZOO ${ }^{\mathrm{TM}}$ Coral Blue Light AZ20009, 30W, 436nm and AZOO ${ }^{\mathrm{TM}}$ Aquarium Green Light AZ72039, 30W, 480nm). The intensity of light reaching at the surface of each aquarium was $590 \mathrm{Lux}$ measured with a Lux meter.

After 10 days, in four aquaria of each colour compartment, an acute stressor was imposed. The other aquaria were used as control groups. The acute stressor was chasing off the fish with a pen net for 60s (BARCELLOS et al., 1999). One hour after the stressor, two fish from each aquaria were sampled, 8 in each one of the six groups (stressed and control of each light regime) totalizing 48 fish. This time was established based in our previous results (BARCELLOS et al., 2001).

For blood sampling all fish in all aquaria were anaesthetised with buffered MS222 (Finquel ${ }^{\circledR}, 300 \mathrm{mg} /$ L), previously dissolved in one liter of water and added to the aquaria to reduce the stress caused by capture. After complete immobilization and loss of orientation, the fish were captured and blood samples ( 0.1 to $0.30 \mathrm{~mL}$ ) were taken from the severed caudal peduncle with sterile microhematrocrit tubes. The time from anaesthesia and blood collection of all fish did not exceed one minute. The tubes were centrifuged (3000g, $10 \mathrm{~min}$ ) in a microhematocrit centrifuge. The plasma was collected with a Hamilton seringe of $50 \mu$, transferred to Eppendorf tubes, and stored at $-25^{\circ} \mathrm{C}$ until required for analysis. Cortisol was measured in duplicate samples of unextracted plasma with a commercially available EIAgen ${ }^{\mathrm{TM}}$ CORTISOL test (BioChem ImmunoSystems). The results were validated with the standard curve of the kit. The intrassay coefficient of variation was $6 \%$.

Results are presented as mean \pm S.E.M., and were analysed with an InsTat Sigma statistical package. The differences between cortisol levels of control and stressed fish from each light regime were compared by Student t-test. The cortisol values of all treatment groups and especifically of the three control groups and stressed groups were compared by analysis of variance (ANOVA) followed by Tukey's multiple range test. Statistical significance was accepted for $\mathrm{P}<0.05$. 


\section{RESULTS AND DISCUSSION}

The mean cortisol levels of control and stressed fish from each light regime are shown in table 1. The analysis of control groups of the three light regimes did not show any differences. Analysis of the differences between the post stress groups of the three light regimes showed that fish kept under white and green light had a statistically higher value than nonstressed controls. When comparing the pre- and poststress groups in each light regime, only fish exposed to green light showed an elevation on cortisol levels.

Chasing fish with a pen net for 60 s increased cortisol levels in fish kept in green and white light. In contrast, no significant effect occurred when fish were maintained under blue light, probabaly due to slight high control values.

An elevation of plasma cortisol concentration after acute stressors in teleost fish has been described for several species (BARTON \& IWAMA, 1991; WENDELAAR BONGA, 1997) including jundiá (BARCELLOS et al., 2001; 2004a).

The un-stressed control values of cortisol in fish exposed to different light regimes are similar to those previously described for jundiá (BARCELLOS et al., 2001, 2004a). Pre-stress values of cortisol ranging from $5-50 \mathrm{ng} / \mathrm{mL}$ are reported for other several species as reviewed by BARRETO \& VOLPATO, 2004. In a review by BARTON \& IWAMA (1991), few papers about fish of the family Siluridae were cited, and those cited were all of Ictalurus punctactus (Rafinesque), with pre-stress cortisol levels varying from 5 to 51ng/ $\mathrm{mL}$ and post-stress levels varying from 30 to 309ng/ $\mathrm{mL}$. The cortisol peak values (the peak occurs $1 \mathrm{~h}$ post stressor in jundiá, BARCELLOS et al., 2001) found for fingerlings in the present study varied from 30 to $50 \mathrm{ng} /$ $\mathrm{mL}$, and are lower than the ones found for other age categories for jundiá (BARCELLOS et al. 2001, 2002, 2003 and 2004a). Several factors may contribute to differences in cortisol levels among species and among

Table 1 - Cortisol concentrations (ng/mL) determined $1 \mathrm{~h}$ after acute stressor exposed fish and control fish, after maintenance by 10 days in white, blue and green ligth.

\begin{tabular}{lccc}
\hline Group & \multicolumn{3}{c}{ Ligth color regime } \\
\hline \multirow{3}{*}{ Control } & White & Blue & Green \\
Post-stress & $17.3 \pm 4.4 \mathrm{aA}$ & $23.5 \pm 6.4 \mathrm{aA}$ & $18.0 \pm 7.6 \mathrm{aA}$ \\
& $30.3 \pm 6.0 \mathrm{bA}$ & $35.3 \pm 8.7 \mathrm{aA}$ & $50.4 \pm 8.4 \mathrm{bB}$ \\
\hline
\end{tabular}

Different small letters in the columns indicates significative difference (Student's T test, $\mathrm{P}<0.05$ ) between control and stressed groups into the specific colour. Different capital letters in lines indicates significative difference between colours (ANOVA folowed by Tukey's multiple range test, $\mathrm{P}<0.05$ ). specimens from the same species such as age, sex, weigth, physiological condition and also the severity and magnitude of the stressor (SUMPTER et al., 1985).

The specific effect of blue light on the stress response was first reported for fish, by VOLPATO \& BARRETO (2001) for Nile tilapia. Blue light also changes fish behavior (KAWAMOTO \& TAKEDA, 1951; LOUKASHKIN \& GRANT, 1959; FANTA, 1995). Effects of the background colour (tanks walls) were assessed by ROTLANT et al. (2003) for Pagrus pagrus, and the authors have postulated that this effect is mediated by the hypothalamus-pituitary-interrenal cells (HPI) axis and the hypothalamus-pituitary-melanophore axis. The present study, similarly to that published by VOLPATO \& BARRETO (2001), supports the idea that colour of the light influences the HPI axis.

The results presented herein showed that green light increases the acute stress response caused by handling in jundiá. The green colour of the light was reported as welfare inducer in Brycon cephalus (Günther) (VOLPATO, 2000) and Sardinops caerulea (Girard) (LOUKASHKIN \& GRANT, 1959). In contrast, in our experiment the green light evoked a higher cortisol response than the white and blue light. No work relating this type of effects was found.

The activity of the $\boldsymbol{R}$. quelen is diminished during the day and this species is more active during the nigth when searching for food (GOMES et al., 2000). PIAIA et al. (1999) reported that jundiá in experimental aquaria shows an aversion to light, seeking dark refuges. The green light effect on the stressor-induced increase in cortisol levels is difficult to explain, but since in natural habitats the environmental colour is a characteristic which varies according to place, and may even change over time in the same habitat, we suggest that the response to green light is associated with the predominant habitat colour. As reviewed by GOMES et al. (2000), the jundiá habitat is the bottom of rivers with low water flow where the fish spend the day in hidden places. In this environment green light may be absent. The effect of light intensity was not considered in our experiment, since the illumination of three colour lamps was the same (590Lux).

A last comment concerns the applicability of light management in aquaculture. Since stressors alter the energy metabolism and the growth in fish (WENDELAAR BONGA, 1997) and can negatively modulate the immune system (BARTON \& IWAMA, 1991) as has also been shown in jundiá (BARCELLOS et al., 2004b), practices that can reduce and/or prevent the stress reponse in fingerlings are very important to increase food conversion and reduce fish losses due parasitic and bacterial pathologies. The preference of jundiá for dark environments is well known to jundiá 
researchers and aquaculturists. However, keeping jundiá fingerlings in completely dark rooms is unfeasible in commercial practices. It is hardly possible to turn the culture facilities completely dark, due to the fact that humans working with these fish need a minimum of light

\section{CONCLUSION}

Our results strongly suggest that colour light regime may be a modulative factor of cortisol response to stressors and that green light seems to be the worst alternative to illuminate jundiá indoor experimentation facilities or even fish transportation. At this stage, more studies, including other colours of light and regimes of illumination, are necessary for the complete elucidation of colour-induced changes $\boldsymbol{R}$. quelen_stress response and this will be the focus of continuing studies.This study was developed in accordance with national and instituonal guidelines for the the protection of human beings and animal welfare.

\section{AKNOWLEDGEMENTS}

This study was supported by grants from FAPERGS 01/1282-6 (Fundação de Amparo a Pesquisa do Estado do Rio Grande do Sul), SCI-EMBRAPA-PRODETAB 0149/2001/2 (Secretaria de Cooperação Internacional, Empresa Brasileira de Pesquisa Agropecuária) and Divisão de Pesquisa da Universidade de Passo Fundo (UPF). The authors are indebted to academics Rodrigo Kramer Baldissera, Marina Raganin de Lima, Alexandra Bedin, Jovani Finco and to biologist Ana Paula Benaduce, for skillful help at the experimental facilities and laboratory. The authors thank Dr. G. Volpato for papers, technical discussion and help during the experiment and analysis of the results. LC Kreutz have a CNPq fellowship (300259/ 2003-4).

\section{REFERENCES}

BARCELLOS, L.J.G. et al. Plasmatic levels of cortisol in the response to acute stress in Nile tilapia (Oreochromis niloticus) previously exposed to chronic stress. Aquaculture Research, Oxford, v.29, n.6, p.437-445, 1999.

BARCELLOS, L.J.G. et al. Haematological and biochemical characteristics of male jundiá (Rhamdia quelen Quoy \& Gaimard Pimelodidae) and hormonal and biochemical changes after acute stress. Aquaculture Research, Oxford, v.34, p.1465-1469, 2003.

BARCELLOS, L.J.G. et al. Nursery rearing of jundiá, Rhamdia quelen (Quoy \& Gaimard) in cages: cage type, stocking density and stress response to confinement. Aquaculture, Amsterdã, v.232, n.1-4, p.383-394, 2004a.

BARCELLOS, L.J.G. et al. Hematological changes in jundiá (Rhamdia quelen Quoy \& Gaimard Pimelodidae) provoked by usual aquaculture practices, with empahsis on immunosupressive effects. Aquaculture, Amsterdan, v.237, n.1-4, p.229-236, 2004b.

BARCELLOS, L.J.G. et al. Plasma levels of cortisol and glucose in response to capture and tank transference in Rhamdia quelen (Quoy \& Gaimard), a South American Catfish. Aquaculture Research, Oxford, v.32, n.3, p.123-125, 2001.

BARCELLOS, L.J.G. et al. Plasma steroid concentrations in relation to the reproductive cycle of cultured male Rhamdia quelen. Journal of Fish Biology, Oxford, v.61, n.3, p.751763, 2002.

BARRETO, R.E.; VOLPATO, G.L. Caution for using ventilatory frequence as an indicator of stres in fish. Behavioural Processes, Amsterdan, v.66, p.43-51, 2004.

BARTON, B.A.; IWAMA,G.K. Physiological changes in fish from stress in aquaculture with emphasis on the response and effects of corticosteroids. Annual Reviews on Fish Diseases, Amsterdan, v.10, p.3-26, 1991.

FANTA, E. Influence of background colour on the behavior of the Oreochromis niloticus (Cichlidae). Arquivos de Biologia e Tecnologia, Curitiba, v.38, p.1237-1251, 1995.

GOMES, L.C. et al. Biologia do jundiá Rhamdia quelen (Teleostei, Pimelodidae). Ciencia Rural, Santa Maria, v.30, n.1, p.179-185, 2000.

KAWAMOTO, N.Y.; TAKEDA, M. The influence of wave lengths of light on the bahavior of young fish. Report of Faculty of Fisheries. Prefectural University of Mie, Mie, v.1, p.4153, 1951.

LOUKASHKIN, A.S.; GRANT, N. Behavior and reactions of the pacific sardine, Sardinops caerulea (Girard), under the influence of white and coloured lights and darkness. Proceedings of California Academy of Sciences, San Francisco, v.29, p.509-548, 1959

PIAIA, R. et.al. Growth and survival of fingerlings of silver catfish exposed to different photoperiods. Aquaculture International, Dordrecht, v.7, n.3, p.201-205, 1999.

ROTLANT, J. et al. Background colours influence on the stress response in cultured red porgy Pagrus pagrus. Aquaculture, Amsterdan, v.223, p.129-139, 2003.

SUMPTER, J.P. et al. Stress-induced elevation on plasma a-MSH and endorphin in brown trout, Salmo truta L. General and Comparative Endocrinology, Duluth, v.59, p.257-265, 1985.

VOLPATO, G.L. Agression among farmed fish. In. FLOS, R.; CRESWELL, L. (Eds). Aqua 2000: responsible aquaculture in the New Millenium. Nice: European Aquaculture Society Special Publication, 2000. №28.

VOLPATO, G.L.; BARRETO, R.E. Environmental blue light prevents stress in the fish Nile tilapia. Brazilian Journal of Medical and Biological Research, Ribeirão Preto, v.34, p.1041-1045, 2001.

VOLPATO, G.L. et.al. Environmental colour affects Nile tilapia reproduction. Brazilian Journal of Medical and Biological Research, Ribeirão Preto, v.37, p.479-483, 2004.

WENDELAAR BONGA, S.E. The stress response in fish. Physiological Reviews, Bathesda, v.77, p.591-625, 1997. 